\title{
The Causes of Poor Performance in Mathematics among Public Senior Secondary School Students in Azare Metropolis of Bauchi State, Nigeria
}

\author{
Tata Umar Sa'ad; Abba Adamu; Abdullahi M. Sadiq \\ Foundations Department School of Education College of Education P. M. B. 044, Azare Bauchi State, Nigeria \\ Mathematics Department School of Science College of Education P. M. B. 044, Azare Bauchi State, Nigeria \\ PES Department School of Education College of Education P. M. B. 044, Azare Bauchi State, Nigeria
}

\begin{abstract}
This study investigated the causes of poor performance in mathematics among public senior secondary schools students in Azare metropolis of Bauchi state, Nigeria. The study sample was 361 in which 300 were students and 61 teachers which were selected from the population of 5,545. The descriptive survey design was used and questionnaire was used in the collection of data. Frequency and simple percentage were used in the analysis of the data. The findings of the study led to the conclusion that students' negative attitude toward mathematics, anxiety and fear of mathematics, inadequate qualified teachers, poor teaching methods, inadequate teaching materials, overcrowded classes were some of the causes of poor performance in mathematics in the study area. The study also found out that developing positive attitude, motivation and proper guidance toward mathematics, using proper methods of teaching the subject, provision of relevant teaching materials, additional classrooms and furniture, provision of libraries and mathematical laboratories were some of the ways of improving performance in mathematics in the study area. Finally, the study recommended that frequent inter-school competition in mathematics, frequent supervision and inspection by proper authorities as well as enlightenment of parents on importance of children's education should be adopted.
\end{abstract}

Key words: Poor Performance, Mathematics, Public Senior Secondary Schools, Students.

\section{Introduction}

Mathematics is one of the most important school subjects in the curriculum worldwide. It is a subject that has direct relationship with other subjects, particularly technical and sciences. Mathematics is also a subject that cuts across primary and secondary school as a compulsory subject. Umameh, (2011) in Tshabalala and Ncube, (2013) was of the view that mathematics is bedrock and an indispensable tool for scientific, technological and economic advancement of any nation. In addition to that Davies and Hersh, (2012) see mathematics as the important subject not only from point of view of getting an academic qualification at school or college, but also is a subject that prepares the students for the future as well irrespective of which work of life they choose to be a part of. Mefor, (2014) summarized it all by saying that mathematics relates to everything in the universe from the smallest to the largest. Umameh, (2011) added that mathematics is intimately connected to daily life and everybody's life-long planning. Therefore, mathematics is a subject that education and human life cannot function effectively without it.

Equally, in Nigeria, mathematics is given all the necessary importance in the curriculum and all policies related to education, right from primary to higher levels. In relation to that Federal Republic of Nigeria (FGN) (2004) categorically stated that mathematics is one of the core or basic subject for all primary and secondary school children. In addition to that mathematics is one of the compulsory subjects that must be passed at credit level by students before getting admission into any tertiary institution in Nigeria. The secondary school mathematics has the following objectives as identified by Comparative Education Study and Adaptation Centre (CESAC) (1982):

$>$ To develop computational skills and foster the desire and ability to be accurate in a degree relevant to the problem at hand.

$>$ To develop precise, logical and abstract thinking.

$>$ To develop ability to recognize problems and to solve them with related to mathematics knowledge.

$>$ To provide necessary mathematical background for further education.

$>$ To stimulate and encourage creativity, originality and curiosity in the learner.

However, it is disheartening to note that with all the importance attached to mathematics in Nigeria's education system, poor performance is recorded in public examinations in recent time. This poor performance in mathematics is one of the major reason for decline in science and technology courses and development, even though FGN, (1998) emphasis on 60:40 ratio in favour of sciences in the area of admission into higher institutions. Ukeje, (1977) in Ojimba, (2012) was of the view that without mathematics, there is no science, 
without science there is no modern technology and without modern technology there is no modern society. Despite the importance attached to mathematics by all stakeholders in education, senior secondary school students still perform poorly.

The Daily Trust of Wednesday, August 25, 2010 as cited by Sa'ad and Usman (2014) reported that "seventy-five per cent of candidates who sat for May/June WAEC 2010 examinations failed to meet the minimum entry requirement into tertiary institutions. Again, the Daily Trust of $21^{\text {st }}$ August, 2014 in Sa'ad and Rabiu (2014) reveals that the recently released WAEC results indicated that over seventy percent fail in November/December results. 86,612 candidates, representing 29.17 percent of the total number of candidates who sat for the NOV/DEC examinations of West African Examination Council (WAEC), obtained credits in five subjects and above, including Mathematics and English language. Again, the WAEC has released its May/June 2014 WASSCE results, recording mass failure in mathematics and English language. Head of National Office, WAEC Charles Eguridu, while announcing the results said "A total of 529,425 candidates; representing 31.28 percent obtained credits. According to him when compared to the 2012 and $2013 \mathrm{May} / \mathrm{June}$ WASSCE, there was marginal decline in the performance of candidates as 38.81 percent was recorded in 2012 and 36.57 in 2013.

Figure1: A bar chart showing WAEC percentage results of students who made five credits and above including Mathematics and English from 2009 to 2014.

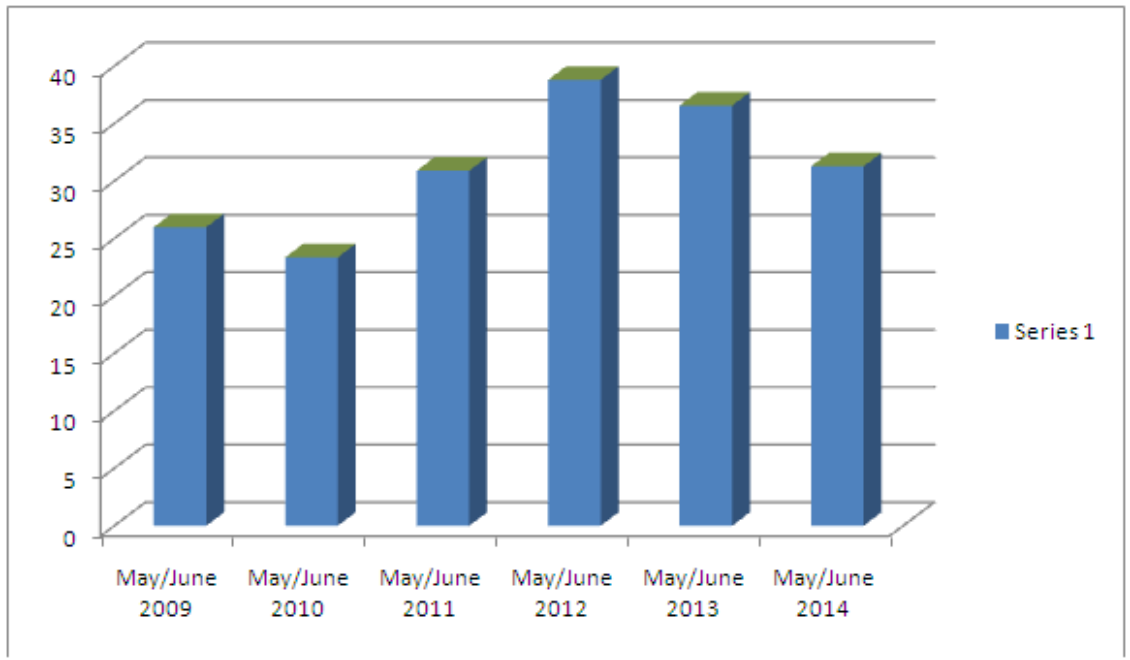

Source: Daily Trust of Thursday $21^{\text {st }}$ August, 2014 in Sa'ad and Rabiu, (2014)

In the bar chart above, in 2009 only $25.99 \%$ made five credits and above including mathematics and English but in 2010 there was a decline to $23.36 \%$. In 2011 the percentage pass of students in WAEC rose to $30.9 \%$ and fortunately continued to rise to $38.81 \%$ in 2012 . However, in 2013 the performance declined to $36.57 \%$, and unfortunately continued to decline to $31.28 \%$ in 2014 .

Therefore, it is against this background that this study investigates into the causes of poor performance in mathematics among senior secondary school students in Azare metropolis of Bauchi state.

\section{Review of Related Literature}

It is evidently seen that there is poor performance in mathematics among senior secondary school students as shown in figure 1 above. The causes of this problem are many and cut across all stakeholders in education. In other words, the causes of poor performance in mathematics among senior secondary school students emanates from the schools, students, teachers as well as the government itself. But in the past many efforts were made to bring a lasting solution to this problem. For instance, Umameh, (2011) stated that events like the comparative Education Study and Adaptation Centre (1976) that took care of the secondary level mathematics syllabus, the Benin Conference (1977) and The National Critique Workshop at Onitsha as well as recently The National Mathematics Centre, all did a lot in ending the problem of poor performance in mathematics.

\section{Causes of Poor Performance in Mathematics among senior Secondary Students}

As said earlier, there are many causes of poor performance in mathematics among senior secondary school students. Bakare, (1994) in Asikhia, (2010) categorizes factors militating against good academic performance into four principal areas which are: 
> Causations resident in the child such as basic cognition skills, physical and health factors, psychoemotional factors, lack of interest in school programme.

$>$ Causations resident in the family such as cognition stimulation/basic intuition during the first two years; type of discipline at home; lack of role model and finance.

$>$ Causations resident in the school such as school location and physical buildings; interpersonal relationship among the school personnel.

$>$ Causations resident in the society such as instability of educational policy; under-funding of educational sector; leadership; job losses.

Specifically, many studies and authorities presented many causes of poor performance in mathematics among students. For instance, Vudla, (2012) in Tshabalala and Ncube, (2013) was of the view that shortage of well trained teachers, inadequate of teaching facilities, lack of fund to purchase necessary equipment, poor quality of textbooks, large classes, poorly motivated teachers, lack of laboratories and libraries, poorly coordinated supervisory activities, interference of the school system by the civil service, incessant transfers of teachers and principals, automatic promotions of pupils, the negative role of public examinations on the teaching learning process and inequality in education opportunities all hamper the smooth acquisition of mathematics knowledge.

In addition to the above causes of poor performance in mathematics, STAN, (2002) as cited by Ojimba, (2012) was of the view that prominent causes of poor performance in mathematics are:

$>$ Acute shortage of qualified professional mathematics teachers.

$>$ Exhibition of poor knowledge of mathematics content by many mathematics teachers.

$>$ Overcrowded mathematics classrooms.

$>$ Students negative attitude toward mathematics.

$>$ Undue emphasis on the coverage of mathematics syllabus at the expense of meaningful learning of mathematics concepts.

$>$ Inadequate facilities and mathematics laboratories.

In another vein, Shield and Kelly, (1999) in National Institute for Educational Development

(2010) found out in Britain that the reasons for poor performance in mathematics from the point of views of principals are:

$>$ Lack of learning support;

$>$ Principal teachers' dissatisfaction with the in-career training of teachers in mathematics;

$>$ Perceived shortage of instructional resources for teaching mathematics;

> Learners taught by teachers who have not participated in career professional development;

> Mathematics contents were not fully covered. Emphasis is placed on few areas that involve numbers.

Other causes of poor performance in mathematics among senior secondary school students include misconception of the subject (mathematics) as difficult one, fear and anxiety. Wikipedia Free Encyclopedia, (2014) stated that students often develop mathematical anxiety in schools, often as a result of learning from teachers who are themselves anxious about their mathematical abilities in certain areas. Attwood, (2014) attributed poor performance in mathematics to parental attitude, interrupted teaching, poor teaching and dyscalculia. Karue and Amukowa, (2013) pointed out that lack of meaningful library and laboratory, qualified teachers, home environmental factors and family backgrounds as well as little participation of parents in the education of their children as the main causes of poor performance in mathematics in Kenya certificate of secondary examination in Embu Distriuct in Kenya.

Therefore, it is clear that the causes of poor performance in mathematics among senior secondary school students are many and varied but they fall under school based causes, teacher and students personal causes. Causes like inadequate qualified teachers, instructional materials, libraries and laboratories, poor attitude of students, improper teaching methods, anxiety, home background, overcrowded classrooms, interrupted teaching, dyscalculia, poorly motivated teachers and so on and so forth bring about poor performance in mathematics among senior secondary school students.

\section{Ways of Improving the Performance of Senior Secondary school Students in Mathematics}

Many ways are suggested by teachers, students, and organizations like STAN and National Mathematical Center on how to improve the performance of students in mathematics. Edukugho, (2010) stated that the government recognized the importance of mathematics in science and technology and in fact in all areas of human knowledge. Hence, government established the National Mathematical Center and has been funding it as one of its parastatals. MAN also is doing a lot in the area of promoting effective mathematical teaching and research.

Mbugua, Kibet, Muthaa and Nkonke, (2012) were of the view that mathematics performance of students can be improved by provision of proper staffing, teaching and learning materials, curriculum, 
motivation and attitudes, and fees and levies. On the other hand, Gitaari, Nyaga, Muthaa and Reche were of the opinion that ways of improving performance of students in mathematics include creation of positive attitude towards mathematics, administering of more examinations and quizzes, provision of adequate teaching and learning materials, motivation, completion of the syllabus in time, provision of adequately trained mathematics teachers, using variety of teaching methods as well as monitoring of lesson by the school administration. Karue and Amukowa, (2013) were of the opinion that provision of instructional materials, library, laboratory and other physical facilities, developing good rapport with parents by the head teachers, reducing students and teachers ratio to manageable size are some of the ways of improving performance in mathematics in Embu District in Kenya.

In another vein, Ojimba, (2012) suggested four strategies for improving the performance of students in mathematics as follows: groupings into students' ability during teaching of mathematics in the classroom; the strategy of constructivism should be imbibed in teaching mathematics, that is for students to learn and sustain their learning they must be in control of their learning. He also added that use of instructional aids and games as well as using computer-aided instruction are the strategies that can be used to improve performance of students in mathematics.

Edukugho, (2010) quoted Chief Kieth Richards, Managing Director, Promasidor Nigeria Limited explained that the mathematics competition A sponsorship nationwide is part of its Corporate Social Responsibility (CSR) as a way of addressing the following:

$>$ Changing the perception of Nigerian students that mathematics is a very difficult subject.

$>$ Reversing the negative statistics from WAEC showing a high failure rate in mathematics exams.

$>$ Enhancing the understanding that mathematics is the bedrock of technological inventions and growth.

$>$ Ensuring that students pass mathematics to facilitate admission for higher studies in numerate academic disciplines.

$>$ Awakening a conscious interest for mathematics amongst pupils from their cradle age.

$>$ Creating a credible medium for identifying, encouraging and rewarding brilliance.

Therefore, it is clear that there are many ways that can be followed in order to improve the performance of secondary school students in mathematics, such as the provision of adequate facilities both teaching and physical, qualified mathematics teachers, developing positive attitude of students towards mathematics, involvement of parents in the education of their children, using proper methods of teaching the subject, organization of quizzes and competition among and between schools and so on and so forth.

\section{Objectives of the study}

The main objectives of this study are to:

i. Find out the main causes of poor performance in mathematics among public senior secondary school students in Azare metropolis of Bauchi state.

ii. Propose the ways of improving performance in mathematics among public senior secondary school students in Azare metropolis of Bauchi state.

\section{Research Design}

The used in this study was a descriptive survey. This type of design was used because it allowed the researcher to study small sample and later generalized the findings to the whole population. Osuala, (2001) was of the view that in survey research small sample is studied and the findings generalized to the whole population.

\section{Research Questions}

1. What are the main causes of poor performance in mathematics among public senior secondary school students in Azare metropolis of Bauchi state?

2. What are ways of improving performance in mathematics among public senior secondary school students in Azare metropolis of Bauchi state?

\section{Population of the study}

The population of this study comprises of all the public senior secondary school students and their teachers in Azare metropolis, totaling five thousand, five hundred and forty five 5,545 as contained in the table 1 below: 
Table 1: Showing the distribution of the population (students and teachers) of the study.

\begin{tabular}{lllll}
\hline S/No. & Name of School & No. of Students & No. of Teachers \\
\hline 1. & G. G. C. Azare & 978 & 63 & Total \\
2. & G. C. D. S. S. Azare & 914 & 48 & 962 \\
3. & G. D. S. S. Azare & 1,574 & 65 & 1,639 \\
4. & G. D. S. S. Matsango, Azare & 464 & 53 & 517 \\
5. & G. D. T. C. Azare & 518 & 48 & 566 \\
6. & G. D. S. S. Nasarawa, Azare & 651 & 33 & 684 \\
7. & Married Women Sec. Sch. Azare & 110 & 16 & $\mathbf{3 2 6}$ \\
Total & & $\mathbf{5 , 2 1 9}$ & $\mathbf{3 2 6}$ & $\mathbf{5 , 5 4 5}$ \\
\hline
\end{tabular}

Source: Katagum Zonal Education Office, Azare, 2014.

\section{Sample for the study}

The sample for this study was three hundred and sixty-one students and teachers selected using disproportionate stratified random sampling technique, in which three hundred were students and sixty-one teachers. The sample was selected based on Krejcie and Morgan's table for determining sample, (1971). The table 2 below shows the distribution of the sample for this study.

Table 2: Showing the distribution of the sample (students and teachers) of the study.

\begin{tabular}{llllc}
\hline S/No. & Name of School & No. of Students & No. of Teachers & Total \\
\hline 1. & G. G. C. Azare & 58 & 12 & 70 \\
2. & G. C. D. S. S. Azare & 44 & 11 & 14 \\
3. & G. D. S. S. Azare & 76 & 07 & 90 \\
4. & G. D. S. S. Matsango, Azare & 33 & 07 & 40 \\
5. & G. D. T. C. Azare & 33 & 09 & 40 \\
6. & G. D. S. S. Nasarawa, Azare & 52 & 01 & 61 \\
7. & Married Women Sec. Sch. Azare & 04 & 05 \\
Total & & $\mathbf{3 0 0}$ & $\mathbf{6 1}$ & \\
\hline
\end{tabular}

Source: Fieldwork, 2014.

\section{Sampling Technique}

Disproportionate stratified random sampling technique was used in selecting the sample for this study. This is because it permitted the researchers to have representation from all the public senior secondary schools in the study area. Kolo, (1992) was of the opinion that this kind of sampling entails that the random drawing of subjects from the population is not only stratified, but that the stratification reflects an appropriate proportion to the power of each strata of the society.

\section{Instrument for Data Collection}

A self design questionnaire was used in the collection of data for this study. The questionnaire comprises of eighteen items dwelling on the variables of the study. The two Likert Scale formats of "Agreed" and "Disagreed" were used as the response format for the questionnaire.

\section{Validity and Reliability of the Instrument}

The instrument was validated by experts who more than two decades of teaching research methods in College of Education, Azare. This was done in order to make instrument measure what it was set measure.

The reliability of the instrument was determined using test-retest method of reliability. The instrument was first used on twenty members of the population and after one week the same instrument was administered to the same people. The two results were correlated using Pearson Product Moment Correlation Coefficient and result found was 8.0. This makes the instrument very reliable because it measured at different times what it was supposed to measure.

\section{Data Analysis Procedures}

The data collected was analyzed using frequency and simple percentage.

\section{Data Presentation and Analysis}

This section focuses on the presentation and analysis of the collected data from the respondents.

Research Question 1: What are the main causes of poor performance in mathematics among public senior secondary school students in Azare metropolis of Bauchi state? 
Table 3: Showing responses obtained from research question one.

\begin{tabular}{|c|c|c|c|}
\hline \multirow[b]{2}{*}{ S/No. } & \multirow[b]{2}{*}{ Questions } & \multicolumn{2}{|c|}{ Responses } \\
\hline & & Agreed \% & Disagreed \% \\
\hline 1. & $\begin{array}{l}\text { Students' negative attitude toward mathematics cause poor performance in the } \\
\text { subject among public senior secondary school students in Azare metropolis of } \\
\text { Bauchi state. }\end{array}$ & $308(85 \%)$ & $53(15 \%)$ \\
\hline 2. & $\begin{array}{l}\text { Anxiety and fear toward mathematics cause poor performance in the subject } \\
\text { among public senior secondary school students in Azare metropolis of Bauchi } \\
\text { state. }\end{array}$ & $302(84 \%)$ & $59(16 \%)$ \\
\hline 3. & $\begin{array}{l}\text { Inadequate qualified teachers of mathematics cause poor performance in the } \\
\text { subject among public senior secondary school students in Azare metropolis of } \\
\text { Bauchi state. }\end{array}$ & $297(82 \%)$ & $64(18 \%)$ \\
\hline 4. & $\begin{array}{l}\text { Using inappropriate or poor methods in teaching mathematics by teachers cause } \\
\text { poor performance in the subject among public senior secondary school students in } \\
\text { Azare metropolis of Bauchi state. }\end{array}$ & $281(78 \%)$ & $80(12 \%)$ \\
\hline 5. & $\begin{array}{l}\text { Inadequate teaching materials of mathematics cause poor performance in the } \\
\text { subject among public senior secondary schools in Azare metropolis of Bauchi } \\
\text { state. }\end{array}$ & $350(97 \%)$ & $11(3 \%)$ \\
\hline 6. & $\begin{array}{l}\text { Overcrowded or large classes cause poor performance in mathematics among } \\
\text { public senior secondary school students in Azare metropolis of Bauchi state. }\end{array}$ & $342(95 \%)$ & $19(5 \%)$ \\
\hline 7. & $\begin{array}{l}\text { Inadequate facilities like libraries and mathematics laboratories cause poor } \\
\text { performance in the subject among public senior secondary school students in } \\
\text { Azare metropolis of Bauchi state. }\end{array}$ & $352(98 \%)$ & $09(2 \%)$ \\
\hline 8. & $\begin{array}{l}\text { Lack of frequent supervision and inspection of mathematics teachers by both the } \\
\text { school administration and ministries of education cause poor performance in the } \\
\text { subject among public senior secondary school students in Azare metropolis of } \\
\text { Bauchi state. }\end{array}$ & $330(91 \%)$ & $31(9 \%)$ \\
\hline 9. & $\begin{array}{l}\text { Lack of parental involvement in the education of their children cause poor } \\
\text { performance in mathematics among public senior secondary school students in } \\
\text { Azare metropolis of Bauchi state. }\end{array}$ & $353(98 \%)$ & $08(2 \%)$ \\
\hline
\end{tabular}

Source: Fieldwork, 2014.

In table 3 above, $85 \%$ of the respondents were of the opinion that students' negative attitude toward mathematics cause poor performance in the subject among public senior secondary school students. On the other hand, $84 \%$ were of the view that anxiety and fear of mathematics cause poor performance in it. $82 \%$ were of the view that inadequate qualified teachers of mathematics cause poor performance in the subject. $78 \%$ were of the opinion that using poor methods of teaching mathematics cause poor performance in it. About $97 \%$ of the respondents were of the view that inadequate mathematics teaching materials cause poor performance in the subject. 95\% were of the view that overcrowded or large classes of mathematics cause poor performance in the subject. $98 \%$ were of the view that lack of facilities like libraries and mathematics laboratories cause poor performance in the subject. $91 \%$ were of the view that lack of frequent supervision and inspection of mathematics teachers cause poor performance in the subject. Finally, $98 \%$ of the respondents were of the view that lack of parental involvement in the education of their children cause poor performance in mathematics among public senior secondary school students.

Therefore, it is obvious that student' negative attitude toward mathematics, anxiety and fear of the subject, inadequate qualified teachers, poor methods of teaching the subject, inadequate mathematics teaching materials, overcrowded or large classes, lack of libraries and laboratories, lack of supervision and inspection of teachers and lack of parental participation in education of children are some of the main causes of poor performance in mathematics among public senior secondary school students in Azare metropolis of Bauchi state.

Research Question 2: What are the ways of improving performance in mathematics among public senior secondary school students in Azare metropolis of Bauchi state?

Table 4: Showing responses obtained from research question two.

\begin{tabular}{|c|c|c|c|}
\hline \multirow[b]{2}{*}{ S/No. } & \multirow[b]{2}{*}{ Questions } & \multicolumn{2}{|c|}{ Responses } \\
\hline & & Agreed \% & Disagreed \% \\
\hline 1. & $\begin{array}{l}\text { Developing positive attitude, motivation as well as proper guidance towards } \\
\text { mathematics can improve the performance of public senior secondary school } \\
\text { students in Azare metropolis of Bauchi state. }\end{array}$ & $308(85 \%)$ & $53(15 \%)$ \\
\hline 2. & $\begin{array}{l}\text { Provision of qualified and adequately trained mathematics teachers can improve } \\
\text { the performance of public senior secondary students in Azare metropolis of Bauchi } \\
\text { state. }\end{array}$ & $301(83 \%)$ & $60(17 \%)$ \\
\hline 3. & $\begin{array}{l}\text { Using appropriate methods of teaching mathematics (child-centered approaches) } \\
\text { can improve the performance of public senior secondary school students in the } \\
\text { subject in Azare metropolis of Bauchi state. }\end{array}$ & $298(83 \%)$ & $63(17 \%)$ \\
\hline 4. & $\begin{array}{l}\text { Provision of adequate and relevant mathematics materials can improve the } \\
\text { performance of public senior secondary school students in the subject in Azare }\end{array}$ & $309(86 \%)$ & $52(14 \%)$ \\
\hline
\end{tabular}




\begin{tabular}{|c|c|c|c|}
\hline 5. & $\begin{array}{l}\text { metropolis of Bauchi state. } \\
\text { Provision of physical facilities like additional classrooms and furniture can } \\
\text { improve the performance of public senior secondary school students in the subject } \\
\text { in Azare metropolis of Bauchi state. }\end{array}$ & $310(86 \%)$ & $51(14 \%)$ \\
\hline 7. & $\begin{array}{l}\text { Proper supervision and inspection by the school administrations and other } \\
\text { appropriate organs can assist in improving the performance in mathematics of both } \\
\text { the teachers and students of public senior secondary schools in Azare metropolis of } \\
\text { Bauchi state. }\end{array}$ & $300(83 \%)$ & $61(17 \%)$ \\
\hline 8. & $\begin{array}{l}\text { Good school-community participation as well as active parental involvement in the } \\
\text { education of children can help in improving the performance of public senior } \\
\text { secondary school students in Azare metropolis of Bauchi state. }\end{array}$ & $290(80 \%)$ & $71(20 \%)$ \\
\hline 9. & $\begin{array}{l}\text { Adopting and using of computer assisted (CAT) by our present day mathematics } \\
\text { teachers can help in improving the performance of public senior secondary school } \\
\text { students in Azare metropolis of Bauchi state. }\end{array}$ & $288(80 \%)$ & $73(20 \%)$ \\
\hline
\end{tabular}

Source: Fieldwork, 2014.

In table 4 above, $85 \%$ of the respondents were of the view that developing positive attitude, motivation and proper guidance to students can help in improving their performance in mathematics. $83 \%$ were of the view that provision of qualified and adequately trained mathematics teachers can help in improving the performance of students in the subject. 83\% were of the view that using appropriate methods of teaching, particularly childcentered approaches can help in improving the performance of students in the subject. $86 \%$ were of the opinion that provision of adequate and relevant mathematics teaching materials can help in improving the performance of students in the subject. $85 \%$ were of the view that provision of libraries and mathematical laboratories can help in improving the performance of students in the subject. $83 \%$ were of the opinion that proper supervision and inspection of mathematics teachers can improve the performance of students in the subject. $80 \%$ were of the opinion that good school-community participation can improve the performance of students in mathematics. Finally, $80 \%$ were of the view that use of computer assisted instruction can help in improving the performance of students in mathematics.

Therefore, it is obvious that developing positive attitude, motivation and proper guidance toward mathematics, provision of qualified and adequately trained mathematics teachers, use of child-centered teaching approaches, provision of adequate and relevant mathematics teaching materials, provision of more classrooms and furniture, provision of libraries and mathematical laboratories, proper supervision and inspection of mathematics teachers, good school-community relationship as well as adoption and usage of computer assisted instruction in teaching the subject are among some of the ways of improving the performance in mathematics among the senior secondary school students in Azare metropolis of Bauchi state.

\section{Discussion of Results}

The discussion of results is presented according to research questions raised in this study.

\section{Research Question One}

The result of the analysis of research question one showed that students' negative attitude toward mathematics, anxiety and fear, inadequate qualified teachers of mathematics, poor teaching methods, inadequate mathematics teaching materials, overcrowded or mathematics classes, lack of libraries and mathematical laboratories, lack of supervision and inspection of mathematics teachers as well as lack of parental participation in the education of children are some of the main causes of poor performance in mathematics among public senior secondary school students in Azare metropolis of Bauchi state.

Therefore, the findings of this study tally with the findings of Bakare, (1994) in Asikhia, (2010), Vudla, (2012) in Tshabalala and Ncube, (2013), STAN, (2002) in Ojimba (2012), Shield and Kelly, (1999) in NEID, (2010), Wikipedia Free Encyclopedia, (2014), Attwood, (2014) and Karue and Amukowa, (2013) who found out that students' negative attitude toward mathematics, anxiety and fear of mathematics, poor teaching methods, inadequate qualified mathematics teachers, large classes, lack of libraries and laboratories as well as lack of parental participation in the education of the children are some of the main causes of poor performance in mathematics.

\section{Research Question Two}

The result of the analysis of research question two showed that developing positive attitude, motivation and proper guidance toward mathematics, provision of qualified and adequately trained mathematics teachers, using child-centered approaches in teaching mathematics, provision of adequate mathematics teaching materials, provision of more classrooms and furniture, provision of libraries and mathematical laboratories, proper supervision and inspection of mathematics teachers, developing good school-community relationship and, 
adoption and use of computer assisted instruction are some of the ways of improving mathematics performance among public senior secondary school students in Azare metropolis of Bauchi state.

Therefore, the findings of this study tally with the findings of Mbugua, Kibet, Muthaa and Nkonke, (2012), Karue and Amukowa, (2013) and Ojimba, (2012) who found out that creation of positive attitude toward mathematics, provision of proper staffing, provision of instructional materials, developing good rapport with the parents, provision of libraries and laboratories, reducing teacher-students ratio, cooperative and child-centered approaches in teaching mathematics are some of the ways of improving performance in mathematics in students. Other areas where this study tally with the studies cited include the monitoring of mathematics lessons, completion of syllabus as well as administering more examinations and quizzes as ways of improving performance in mathematics in students.

\section{Conclusion}

Based on the findings of this study, the following conclusions were made:

That students' negative attitude toward mathematics, anxiety and fear, inadequate qualified teachers of mathematics, poor teaching methods, inadequate mathematics teaching materials, overcrowded or mathematics classes, lack of libraries and mathematical laboratories, lack of supervision and inspection of mathematics teachers as well as lack of parental participation in the education of children are some of the main causes of poor performance in mathematics among public senior secondary school students in Azare metropolis of Bauchi state.

That developing positive attitude, motivation and proper guidance toward mathematics, provision of qualified and adequately trained mathematics teachers, using child-centered approaches in teaching mathematics, provision of adequate mathematics teaching materials, provision of more classrooms and furniture, provision of libraries and mathematical laboratories, proper supervision and inspection of mathematics teachers, developing good school-community relationship and, adoption and use of computer assisted instruction are some of the ways of improving mathematics performance among public senior secondary school students in Azare metropolis of Bauchi state.

\section{Recommendations}

Based on the findings of this study, the following recommendations were provided:

Frequent inter-school competition in mathematics should be organized by Katagum Zonal Education Office, Azare at least three times far term.

The annual competition and quiz organized by Mathematical Association of Nigeria (MAN) should be extended to all nook and corners of Nigeria (Urban and Rural) and it should be on quarterly basis.

Frequent supervision and inspection by the state ministry of education as well as Katagum Zonal Office should be carried out in order to see and assess the teaching of mathematics and other subjects in the study area.

Parents should be enlightened on the importance of their involvement in the education of their children and its attendant benefit in the performance of students.

Katagum Education Development Association (KEDA) as a non-governmental organization in the study area which is providing scholarship to university students studying medicine should include students studying mathematics. This can make the secondary school students to work hard in mathematics before even proceeding to higher level.

Good school-community relationship should be developed and maintained in order to enjoy its attendant benefits which ultimately will lead to improvement in performance of students in mathematics and other subjects.

Guidance and counseling units should be set up in our secondary schools and they should be guiding and counseling students on the educational, personal and social issues affecting students. This will definitely help them to change their view with regard to mathematics and can help in improving their performance in it.

\section{References}

[1]. Attwood, T. (2014). Why are Some Students so Poor at Maths? Retrieved on $19^{\text {th }}$ October 2014 from https://www.senmagazine.co.uk/articles/articles/senarticles/why-are- some-people-so-poor-at-maths

[2]. Asikhia, O. A. (2010). Students and Teachers' Perception of the Causes of Poor Academic

[3]. Performance in Ogun State Secondary Schools [Nigeria]: Implication for Counseling for National Development. Retrieved on 11 November, 2014 from http://connection.ebscohost.com/c/articles/50743662/students-teachers-perception-causes-poor-academicperformance-ogun-state-secondary-schools-nigeria-implications-couselling-national-development

[4]. CESAC (1982). Nigeria Secondary Schools Mathematics Project. Lagos: CESAC Press.

[5]. Davies, P. J. \& Hersh, R. (2012). The Mathematical Experience. Boston:Mifflin Company.

[6]. Edukugho, E. (2010). Federal Government Moves to Tackle Poor Result in NECO, SSCE Exams

Rufai. Retrieved on $9^{\text {th }}$ October, 2014 from http://www.vanguardngr.com/2010/06/fg-moves-to-tackle-poor-result-in-neco-ssceexams-rufai/

[7]. Federal Republic of Nigeria (1998). National Policy on Education. Lagos: NERDC Press.

[8]. Federal Republic of Nigeria (2004). National Policy on Education. Lagos: NERDC Press. 
[9]. Gitaari, E. M., Nyaga, G., Muthaa, G. \& Reche, G. (2013). Factors Contributing to Students Poor Performance in Mathematics in Public Secondary Schools in Tharaka South District, Kenya.

Retrieved on $9^{\text {th }}$ October, 2014 from http://www.iiste.org/Journals/index.php/JEP/article/view/5281

[10]. Karue, N. \& Amukowa, W. (2013). Analysis of Factors that Lead to Poor Performance in Kenya

Certificate of Secondary Examination in Embu District in Kenya. Retrieved on $19^{\text {th }}$ October, 2014 from http://www.tijoss.com/TIJOSS\%2013th\%20Volume/Amukowa.pdf

[11]. Kolo, A. I. (1992). Essential of Research in Education (A Handbook for Students and Beginning Researchers in Education). Lagos: Text and Leisure Publishers.

[12]. Mbugua, Z. K., Kibet, K. \& Nkonke, G. R.(2012). Factors Contributing to Students' Poor Performance in Mathematics at Kenya Certificate of Secondary Education in Kenya: A Case of Baringo County, Kenya. Retrieved on $19^{\text {th }}$ October, 2014 from http://www.aijcrnet.com/journals/Vol 2 No 6 June 2012/11.pdf

[13]. Mefor, C.(2014). Nigeria: Identifying Problems of Poor Performance in Mathematics and Way Out.Retrieved on $19^{\text {th }}$ October, 2014 from http://allafrica.com/stories/201101200591.html

[14]. National Institute for Educational Development (NEID) (2010).Performance of Learners in Mathematics at Upper Primary Phase in Namibia: Examining Reasons for Low Performance. Retrieved on $19^{\text {th }}$ October, 2014 from http://www.nied.edu.na/publications/research\%20docs/Maths national\%20report\%20Sept 30 \%20DECEMBER\%203rd\%20FEBt h\%20updated\%20_Nambira\%20Aina\%20FINAL.pdf

[15]. Ojimba, D. P. (2012). Strategies for Teaching and Sustaining Mathematics as an Indispensable Tool for Technological Development in Nigeria. Retrieved on $19^{\text {th }}$ October, 2014 from http://www.mcser.org/images/stories/MJSS-Specialissue/MJSS\%202012\%20Special\%20Issue\%20vol203\%20no\%2015/Daso,\%20Peter\%20Ojimba.pdf

[16]. Osuala, E. O. (2005). Introduction to Research Methodology.(Rev. Ed) Onitsha: African Fab Publishers.

[17]. Sa'ad, T. U. \& Usman, R. (2014). The Causes of Poor Performance in English Language Among Senior Secondary School Students in Dutse Metropolis of Jigawa State, Nigeria. Retrieved on $4^{\text {th }}$
November,
2014
from https://www.academia.edu/9126482/The_Causes_of_Poor_Performance_in_English_Language_among_Senior_Secondary_School_ Students_in_Dutse_Metropolis_of_Jigawa_State_Nigeria

[18]. Tshabalala, T. \& Ncube, A. C. (2013). Causes of Poor Performance of Ordinary Level Pupils In Mathematics in Rural Secondary Schools in Nkayi District: Learner's Attritions.

Retrieved on $19^{\text {th }}$ October, 2014 from http://novaexplore.com/NJMBS/wp-content/uploads/sites/4/2014/02/N.JMBS_.4-14.pdf

[19]. Umameh, M. A. (2011). A Survey of Factors Responsible for Students' Poor Performance in Mathematics in Senior Secondary School Certificate Examination (SSCE) in Idah Local Government Area of Kogi State, Nigeria. Reteieved on $4^{\text {th }}$ November, 2014 from

https://www.academia.edu/7671293/A_SURVEY_OF_FACTORS_RESPONSIBLE_FOR_STUDENTS_POOR_PERFORMANCE _IN_MATHEMATICS_IN_SENIOR_SECONDARY_SCHOOL_CERTIFICATE_EXAMINATION_SSCE_IN_IDAH_LOCAL_ GOVERNMENT_AREA_OF_KOGI_STATE_NIGERIA

[20]. Wikipedia Free Encyclopedia, (2014). Mathematics Anxiety. Retrieved on $19^{\text {th }}$ October, $2014 \quad$ From http://en.wikipedia.org/wiki/Mathematical anxiety 